\title{
First report of Lema bilineata Germar (Coleoptera: Chrysomelidae) damaging Physalis peruviana (L.) in Brazil
}

\author{
Adelia Maria Bischoff ${ }^{1,2^{*}}$ (D) Jason Lee Furuie $^{1}$ (i) Alessandra Benatto $^{1}$ (i) \\ Rubens Candido Zimmermann ${ }^{1}$ (i) Emily Silva Araujo ${ }^{1}$ (i) Rayne Baena ${ }^{1}$ (iD \\ Marcia Cristina Herchonvicz de Oliveira ${ }^{1}$ Maria Aparecida Cassilha Zawadneak ${ }^{1}$ (D)
}

'Departamento de Patologia Básica, Universidade Federal do Paraná (UFPR), 81531-980, Curitiba, PR, Brasil. E-mail:adelia_m_@yahoo.com.br. ${ }^{*}$ Corresponding author.

${ }^{2}$ Programa de Pós-graduação em Agronomia, Produção Vegetal, Universidade Federal do Paraná (UFPR), Curitiba, PR, Brasil.

ABSTRACT: Increased production of the Cape gooseberry (Physalis peruviana L.) in Brazil has given rise to interest in identifying the phytophagous species that might damage this crop to inform preventive control and integrated pest management strategies. In this study, we report the occurrence and describe the damage that larvae and adults of Lema bilineata Germar (Coleoptera: Chrysomelidae) cause in P. peruviana. The number of L. bilineata individuals, both larvae and adults, significantly affected the total consumption of $P$. peruviana leaves. We also report, for the first time, three natural enemies, including a fungus, a fly, and an ant, which are associated with this pest in Brazil and may play a role in biological control strategies.

Key words: Cape gooseberry, entomopathogenic fungus, natural enemies.

Primeiro relato de Lema bilineata Germar (Coleoptera: Chrysomelidae) causando dano em Physalis peruviana (L.) no Brasil

RESUMO: Fisális, Physalis peruviana L., é uma cultura em expansão no Brasil, dessa forma a identificação de espécies fitófagas que causam danos nesta cultura é importante para desenvolver controle preventivo e estratégias para o Manejo Integrado de Pragas. Neste estudo, relatamos a ocorrência de Lema bilineata Germar (Coleoptera: Chrysomelidae) no cultivo de P. peruviana e descrevemos os danos causados por suas larvas e adultos. Observou-se que o número de indivíduos de L. bilineata, tanto larvas como adultos, influenciaram significativamente o consumo total de folhas de P. peruviana. Além disso, relatamos pela primeira vez a presença de três inimigos naturais, incluindo um fungo, uma mosca e uma formiga, associados a esta praga no Brasil que poderiam ser utilizados como agentes de controle biológico.

Palavras-chave: Fisális, fungos entomopatogênicos, inimigos naturais.

The Cape gooseberry, Physalis peruviana L. (Solanaceae), is native to the Andean region and is commercially grown in Brazil (MUNIZ et al., 2014) due to its pharmacological and nutritional benefits (SANTOS et al., 2020). It has also become an attractive alternative for small farmers seeking to diversify their crops because of the high added value of its fruits and its low costs of cultivation (PUENTE et al., 2011).

Arthropod pests can limit the production of $P$. peruviana. Identifying and studying pest species is important for the design of effective control methods (AFSAH, 2015). In Brazil, the main pests that have been reported to attack P. peruviana are Aphis sp. Glover (Hemiptera: Aphididae), Edessa rufomarginata De Geer (Heteroptera: Pentatomidae), Phthia picta (Drury) (Hemiptera: Coreidae), Heliothis virescens (Fabricius) (Lepidoptera: Noctuidae), Epitrix sp. (Coleoptera: Chrysomelidae), Manduca sextapaphus (Cramer) (Lepidoptera: Sphingidae) (RUFATO et al., 2013), Edessa meditabunda (Fabricius) (Hemiptera: Pentatomidae) (KRINSKI, 2013), and Tetranychus ludeni (Acari: Tetranychidae) (ALVARENGA SOARES et al., 2014). Since very few pest control products have been registered for this crop, pests have thus far been controlled using 
cultural practices and natural biological control (MUNIZ et al., 2014).

In Argentina, Lema bilineata Germar (Chrysomelidae) has been identified as another arthropod pest attacking this crop (BADO et al., 2000). Lema bilineata is a defoliating insect that feeds on host plants of the Solanaceae family (MONTI et al., 2020). It causes considerable economic damage during its larval and adult phases to solanaceous crops such as tobacco Nicotiana tabacum L., in Argentina (ORMEÑO et al., 2002) and South Africa (BENNETT et al., 1999), and to Physalis viscosa L. in Australia (STEVENS et al., 2010), and P. peruviana in Argentina (BADO et al., 2000) and Italy (SERVIZIO FITOSANITARIO REGIONALE, 2017).

Species of the genus Lema have been reported in Brazil since the 1950s (COSTA LIMA, 1955), where they were not initially considered pests. Later, insects of this genus were reported to cause damage to corn plants, Zea mays L., in the Federal District (LAUMANN et al., 2004) and Acnistus breviflorus Sendtn. (Solanaceae) plants in the state of Rio Grande do Sul (PINHEIRO \& GRAZIA, 2013). This study documents, for the first time, the presence of $L$. bilineata in cultivated $P$. peruviana in Brazil, representing an extension of its geographical distribution. We examined the foliar consumption in larval and adult L. bilineata and observed the presence of three natural enemies associated with this species. These basic aspects are essential for controlling the incidence of this pest.

Between November 2018 and March 2019 , field surveys in $P$. peruviana plantations in the municipalities of Curitiba $\left(25^{\circ} 25^{\prime} 42^{\prime \prime} \mathrm{S}, 49^{\circ} 16^{\prime} 24^{\prime \prime} \mathrm{W}\right)$, Campo Largo (25 27'32'S, 49 $\left.31^{\prime} 55^{\prime \prime} \mathrm{W}\right)$, and

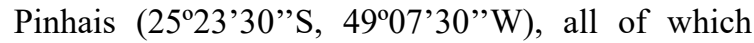
are located in the state of Paraná, southern Brazil, revealed that many plants had been attacked by larvae and adults of chrysomelids. Samples of ten specimens of these insects were collected and sent to the Department of Zoology of the Federal University of Paraná (UFPR), Curitiba, for identification. The specimens were identified by Dr. Germano Henrique Rosado-Neto as L. bilineata. Samples were deposited in the entomological collection of Pe. Jesus Santiago Moure Museum (DZUP), housed within the Zoology Department of UFPR. The collected insects were kept in the laboratory under controlled conditions $(25 \pm 2$ ${ }^{\circ} \mathrm{C}, 60 \pm 10 \% \mathrm{RH}$, and 12:12 h [L:D] photoperiod) with leaves of $P$. peruviana for rearing.

We evaluated the herbivory of $P$. peruviana individuals using leaf blade consumption bioassays. The treatments used to measure leaf consumption were different numbers of third-instar larvae and nonsexed adults aged up to $48 \mathrm{~h}$. Intact, pesticide residuefree leaves of $P$. peruviana were placed into $120 \mathrm{~mL}$ polypropylene containers after first being disinfected with $2 \%$ hypochlorite (one leaf per container). The treatments consisted of a variable number (one, three, or five) of third-instar larvae or adult L. bilineata individuals. Leaves were photographed before and after $48 \mathrm{~h}$ of exposure to the insects. Ten replicates per treatment were carried out. Defoliation estimates were expressed as total and individual consumption and as a percentage of leaf area loss calculated using Easy Leaf Area software (EASLOM \& BLOOM, 2014). A one-way ANOVA was used to analyze total consumption and mean individual consumption data, with the number of L. bilineata individuals per leaf as a factor. Mean separation was carried out using a Tukey test. Normality (ShapiroWilk) and homogeneity of variances (Levene) tests were performed to check the ANOVA assumptions. Statistical analyses were completed in $\mathrm{R}$ version 3.5.2 (R CORE TEAM, 2019).

The duration of the life cycle (from egg to adult) of L. bilineata under the conditions of this study was $26.3 \pm 3.7$ days, which is consistent with findings by BADO et al. (2000). Oviposition of $L$. bilineata usually occurred on the abaxial side of the $P$. peruviana leaves in an isolated pattern. The eggs (Figure 1A) are yellow and elliptical, measuring $0.51 \mathrm{x}$ $0.22 \mathrm{~mm}$; this stage lasted for $4.9 \pm 0.3$ days. The larval stage consisted of four instars, with a duration of 1.9, 1.6, 1.8, and 2.4 days, from the first to fourth instars. Larvae are dark yellow and approximately $6 \mathrm{~mm}$ in length at the fourth instar, with a dark brown to black cephalic capsule (Figure 1B). The insects pupate in a matte white cocoon with approximately $6 \mathrm{~mm}$ in length (Figure 1C). The pupa stage lasted for $12.6 \pm 0.9$ days, twice as long as reported by BADO et al. (2000). In adults, we observed that the coloration of the elytra consisted of alternating bright yellow and dark brown longitudinal lines extending from the base to the apex (Figure 1D). The pronotum was dark in males and light brown in females (Figure 1E). We also observed that the larvae have a fecal shield (Figure 1B). This behavior is common in members of the Criocerinae subfamily, serving as camouflage and defense against predators such as ants and termites (SELMAN, 1988) and parasitoids (OLMSTEAD, 1994).

The leaf consumption bioassay indicated that larvae and adults from the group with the highest number of individuals showed the highest average total and mean individual consumption (Table 1). This increase in individual foliar consumption when 


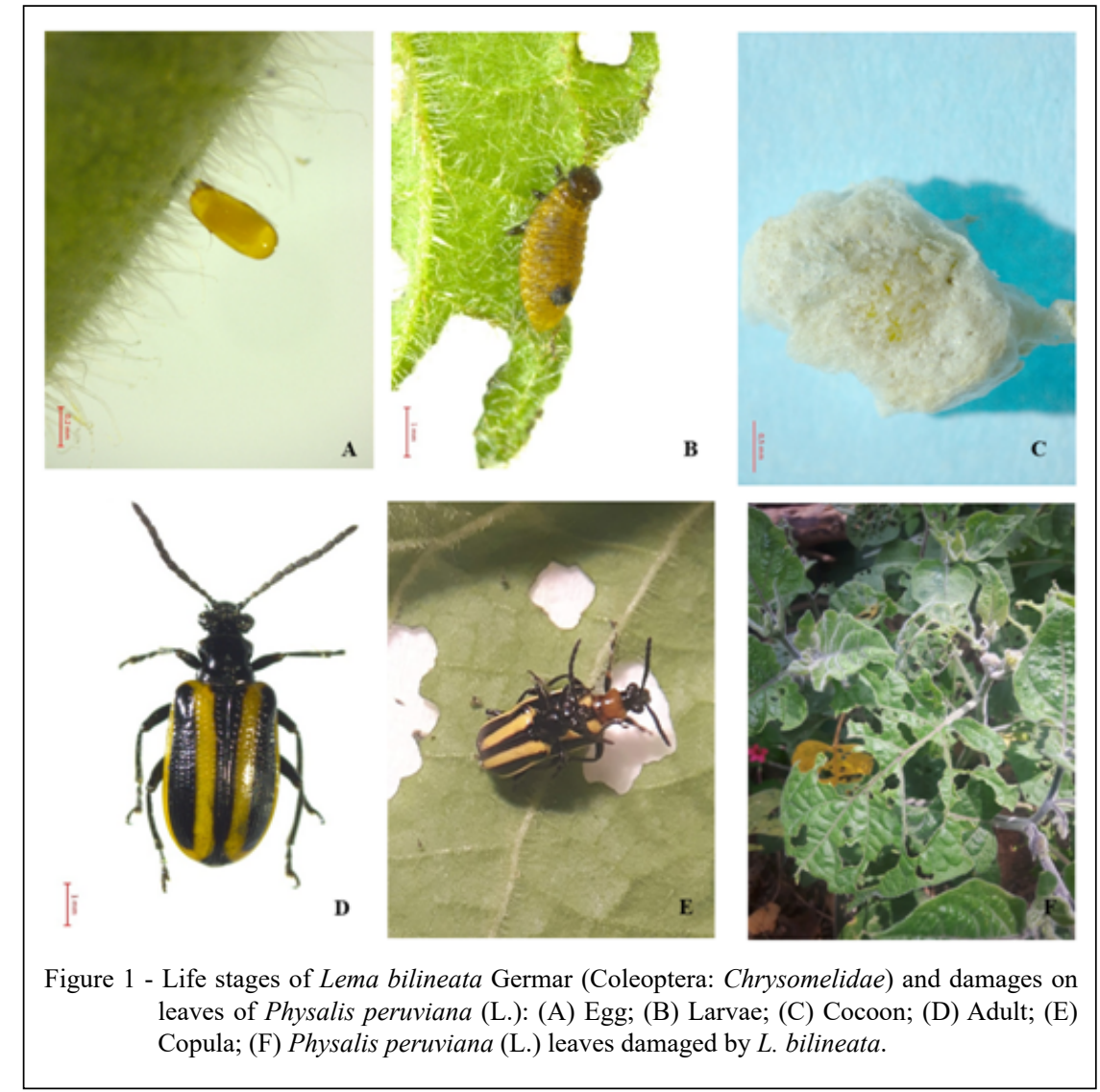

insects are grouped, along with their rapid life cycle, indicates that this species can cause considerable crop damage in a short time (NABITY et al., 2009). The presence of this insect in commercial plantations of $P$. peruviana could; therefore, compromise productivity (Figure 1F) throughout the insect's life cycle.

During the collection and evaluation of L. bilineata larvae, we observed the emergence of

Table 1 - Consumption of Physalis peruviana leaves by different numbers of third-instar larvae and adult individuals of Lema bilineata after $48 \mathrm{~h}$ under controlled conditions $\left(25 \pm 2{ }^{\circ} \mathrm{C}, 60 \pm 10 \% \mathrm{RH}\right.$, and 12:12 h [L:D] photoperiod). Data are given as total and mean individual consumption $\left(\mathrm{cm}^{2}\right) \pm$ standard error.

\begin{tabular}{|c|c|c|c|c|c|c|}
\hline Stage & Number of leaves & Individuals/leaf & Total consumption & $\%$ & Average individual consumption & $\%$ \\
\hline & 10 & 1 & $5.3 \pm 0.2 \mathrm{a}$ & 2.1 & $0.5 \pm 0.2 \mathrm{a}$ & 0.2 \\
\hline \multirow[t]{6}{*}{ Larval } & 10 & 3 & $13.1 \pm 0.1 \mathrm{~b}$ & 4.7 & $0.4 \pm 0.0 \mathrm{ab}$ & 0.2 \\
\hline & 10 & 5 & $34.8 \pm 0.4 \mathrm{c}$ & 13.3 & $0.7 \pm 0.1 \mathrm{~b}$ & 0.3 \\
\hline & & & $\mathrm{F}=81.88$ & & $\mathrm{~F}=10.07$ & \\
\hline & & & $P<0.001$ & & $P=0.006$ & \\
\hline & & & $d f=2$ & & $d f=2$ & \\
\hline & 10 & 1 & $5.9 \pm 0.1 \mathrm{a}$ & 2.4 & $0.6 \pm 0.1 \mathrm{a}$ & 0.2 \\
\hline \multirow[t]{5}{*}{ Adult } & 10 & 3 & $21.0 \pm 0.2 \mathrm{~b}$ & 6.2 & $0.7 \pm 0.1 \mathrm{ab}$ & 0.2 \\
\hline & 10 & 5 & $45.1 \pm 0.3 \mathrm{c}$ & 13.7 & $0.9 \pm 0.1 \mathrm{~b}$ & 0.3 \\
\hline & & & $F=113.74$ & & $\mathrm{~F}=10.39$ & \\
\hline & & & $P<0.001$ & & $P=0.005$ & \\
\hline & & & $d f=2$ & & $d f=2$ & \\
\hline
\end{tabular}

Different letters in the column for a given life stage indicate significant differences $(\mathrm{P}<0.05)$ in consumption by varying numbers of $L$. bilineata individuals per leaf according to the Tukey test. $\%=$ Percentage of the total surface of the leaf; $F=$ value of the ANOVA statistic; $\mathrm{P}=\mathrm{p}$-value; $\mathrm{df}=$ degrees of freedom.

Ciência Rural, v.51, n.9, 2021. 
parasitic flies of the family Tachinidae (Diptera) and the predation of larvae by Pseudomyrmex gracilis (Hymenoptera: Formicidae: Pseudomiyrmicinae) ants, as well as infection of $L$. bilineata adults by Beauveria bassiana (Balsamo) (Hypocreales: Cordycipitaceae). Ant specimens were identified by Dr. Rodrigo M. Feitosa, from the Department of Zoology of the Federal University of Paraná (UFPR), Curitiba. The identification of the fungal isolate was performed according to VICENTE et al. (2008). The identified isolate was deposited in the Microbiological Collections of the Paraná Network (CMRP-Taxonline) as CMRP4485. We did not quantify the abundance of these natural enemies in the present study; however, they may represent alternatives for controlling this pest, highlighting the importance of managing agroecosystems by preserving the biodiversity of beneficial fauna.

\section{ACKNOWLEDGMENTS}

We are grateful to the Coordenação de Aperfeiçoamento de Pessoal de Nível Superior (Capes), Brasil Finance code 001, for awarding a Ph.D. scholarship to the first author and to Fundação Araucária (agreement 38/2019) for a research grant to her supervisor. We thank the taxonomists from the Universidade Federal do Paraná (UFPR), Dr. Germano Henrique Rosado-Neto for the identification of the Coleoptera specimens and Dr. Rodrigo M. Feitosa for the identification of the ant specimens.

\section{DECLARATION OF CONFLICT OF INTEREST}

The authors declare no conflict of interest. The founding sponsors had no role in the design of the study; in the collection, analyses, or interpretation of data; in the writing of the manuscript, and in the decision to publish the results.

\section{AUTHORS' CONTRIBUTIONS}

The authors contributed equally to the manuscript.

\section{REFERENCES}

AFSAH, A. F. E. Survey of insects \& mite associated Cape gooseberry plants (Physalis peruviana L.) and impact of some selected safe materials against the main pests. Annals of Agricultural Sciences, Giza, v.60, p.183-191, 2015. Available from: <https://doi.org/10.1016/j.aoas.2015.04.005>. Accessed: Jun. 12, 2020. doi: 10.1016/j.aoas.2015.04.005.

ALVARENGA SOARES, M. et al. Lesiones de Tetranychus ludeni (Acari: Tetranychidae) en el cultivo de Physalis peruviana (Solanaceae) en Diamantina, Brasil. Revista Colombiana de Entomologia, Bogotá, v.40, n.2, p.187-189, 2014. Available from: $\quad<$ http://www.scielo.org.co/scielo.php?script=sci arttext\&pid $=$ S0120-04882014000200010\&lng $=$ en\&nrm=iso $>$. Accessed: May, 19, 2020
BADO S. G. et al. Aspectos morfológicos, biológicos y de ingesta de Lema bilineata G. (Coleoptera: Chrysomelidae) sobre Physalis peruviana (Solanaceae). Boletin de Sanidad Vegetal Plagas, Buenos Aires, v.27, p.5-10, 2000. Available from: <https://www.researchgate.net/publication/28161549 Aspectos_morfologicos_biologicos_y_de_ingesta_de_Lema_ bilineata_Germ_Coleoptera_Chrysomelidae_sobre_Phisalis_peruviana_L.>. Accessed: Jul. 07, 2020.

BENNETT A. et al. A new record of Lema trilinea White (Coleoptera: Chrysomelidae) on tobacco in South Africa, with reference to the common pest species, Lema bilineata (Germar) (Coleoptera: Chrysomelidae, Criocerinae). African Entomology, v.7, n.2, p.316-319, 1999. Available from: <https: //journals.co.za/ content/ento/7/2/AJA10213589_377>. Accessed: Jun. 05, 2020.

COSTA LIMA, A. Coleopteros. In: Insetos do Brasil. Escola Nacional de Agronomia. Rio de Janeiro, 1955. V.9, ch.XXIX, p.153-154.

EASLOM, H. M.; BLOOM, A. J. Easy Leaf Area: Automated digital image analysis for rapid and accurate measurement of leaf area. Applications in Plant Sciences, v.2, n.7, 1400033, 2014. Available from: <https://doi.org/10.3732/apps.1400033>. Accessed: May, 30, 2020. doi: 10.3732/apps.1400033.

KRINSKI, D. Physalis angulata L. (Solanaceae): a potential hostplant of stink bugs Edessa meditabunda F. (Hemiptera, Pentatomidae). Biota Neotropica, Campinas v.13, n.2, p.336339, 2013. Available from: <https://www.scielo.br/scielo. php?script=sci_arttext\&pid=S1676-06032013000200336\&lng $=$ en\&tlng $=$ en $>$. Accessed: Apr. 29, 2020. doi: 10.1590/S167606032013000200036 .

LAUMANN, R. et al. Diversidade de crisomelídeos-praga (Coleoptera: Chrysomelidae) no Distrito Federal. Brasília: Embrapa Recursos Geneticos e Biotecnologia, 2004. 22p. (Boletim de Pesquisa e Desenvolvimento, 76). Available from: $<\mathrm{https} / / /$ www.embrapa.br/busca-de-publicacoes/-/publicacao/185301/ diversidade-de-crisomelideos-praga-coleoptera-chrysomelidaeno-distrito-federal>. Accessed: Jun. 30, 2020.

MONTI, M. M. etal. Morphological and Molecular Characterization of Lema bilineata (Germar), a New Alien Invasive Leaf Beetle for Europe, with Notes on the Related Species Lema daturaphila Kogan \& Goeden. Insects, v.11, n.5, p.295, 2020. Available from: $<$ https://www.ncbi.nlm.nih.gov/pmc/articles/PMC7290676/>. Accessed: May, 19, 2020. doi: 10.3390/insects11050295.

MUNIZ, J. et al. General aspects of Physalis cultivation. Ciência Rural, v.44, n.6, p.964-970, 2014. Available from: <https://doi. org/10.1590/S0103-84782014005000006>. Accessed: Apr. 29, 2020. doi: $10.1590 /$ S0103-84782014005000006.

NABITY, P. D. et al. Indirect suppression of photosynthesis on individual leaves by arthropod herbivory. Annals of Botany, v.103, p.655-663, 2009. Available from: <https://www.ncbi.nlm. nih.gov/pmc/articles/PMC2707346/>. Accessed: Jun. 24, 2020. doi: $10.1093 / \mathrm{aob} / \mathrm{mcn} 127$.

OLMSTEAD, K. L. Waste products as chrysomelid defenses. Department of Biology, University of South Dakota, Vermillion, v.50, p.311-318, 1994. Available from: <https://link.springer. com/chapter/10.1007\%2F978-94-011-1781-4_24>. Accessed: Jun. 25, 2020. 
ORMEÑO, J. et al. Supervivencia y alimentación comparativa de larvas de Lema bilineata Germar en Datura spp., tabaco y otras solanáceas. Boletin de Sanidad Vegetal Plagas, v.28, p.21-31, 2002. Available from: <https://www.miteco.gob.es/ ministerio/pags/Biblioteca/Revistas/pdf_plagas/BSVP-28-01021-031.pdf $>$. Accessed: May, 19, 2020.

PINHEIRO, P. G.; GRAZIA, J. Morfologia e observações comportamentais de duas espécies neotropicais de Lema (Coleoptera, Chrysomelidae, Criocerinae). In: XXV Salão de Iniciação Científica - UFRGS, Porto Alegre. Resumos XXV Salão IC-UFRGS. Porto Alegre: UFRGS. Available from: $<$ https://lume.ufrgs.br/handle/10183/92718>. Accessed: Jun. 05, 2020.

PUENTE, L. A. et al. Physalis peruviana Linnaeus the multiple properties of a highly functional fruit: a review. Food Research International, v.44, p.1733-1740, 2011. Available from: <https:// doi.org/10.1016/j.foodres.2010.09.034>. Accessed: Jul. 07, 2020. doi: 10.1016/j.foodres.2010.09.034.

R CORE TEAM. R: A language and environment for statistical computing. R Foundation for Statistical Computing, Vienna, Austria, 2019. Available from: <https://www.R-project.org/>. Accessed: Jan. 18, 2020.
RUFATO,A.de R. et al. Acultura da physalis. In: KRETZCHMAR, A.A. et al. Pequenas Frutas. Florianópolis: UDESC, 2013. Serie Fruticultura, v.2, p.143-193. 2013. Available from: <http://ainfo. cnptia.embrapa.br/digital/bitstream/item/108653/1/RUFATOCultura-Physalis.pdf $>$. Accessed: Jul. 09, 2020.

SANTOS, G. C. et al. Polyploidy induction in Physalis alkekengi. Bioscience Journal, v.36, n.3, p.827-835, 2020. Available from: <http://dx.doi.org/10.14393/BJ-v36n3a2020-47729>. Accessed: Jun. 16, 2020. doi: 10.14393/BJ-v36n3a2020-47729.

SELMAN, B. J. Chrysomelids and ants. In: JOLIVET, P. et al. Biology of Chrysomelidae. Kluwer Academic Publishers, Dordrecht/ Boston/London, 1988, v.42, ch. 27, p.463-474.

SERVIZIO FITOSANITARIOREGIONALE. Lema bilineata (Germar) - Crisomelide sudamericano del tabacco. AssesoratoAgricoltura: Regione Campania, Italy, Oct. 02, 2017. Available from: <http://agricoltura.regione.campania.it/difesa/ lema_bilineata.html>. Accessed: May, 21, 2020.

STEVENS, M. M. et al. Detection of Lema bilineata Germar (Coleoptera: Chrysomelidae) in Australia. General and Applied Entomology, v.39, p.1-3. 2010. Available from: <https://www.semanticscholar.org/paper/ Detection-of-Lema-bilineata-Germar->. Accessed: May, 19, 2020. 